\title{
Decomposition and Mineralization Effect of Various Sources of Pig Manure on Water Quality and Nutrients Availability for Agro-Fish System in Benin
}

\author{
H. K. J. Bokossa1 ${ }^{*}$, A. Saïdou ${ }^{2}$, E. Sossoukpe1, D. E. Fiogbé1, D. Kossou ${ }^{3}$ \\ ${ }^{1}$ Laboratory of Research on Wetlands (LRW), Department of Zoology, Faculty of Science and Technique, \\ University of Abomey-Calavi, Cotonou, Benin \\ ${ }^{2}$ Integrated Soil and Crop Management Unit (ISCM), Laboratory of Soil Sciences, Department of Crop Science, \\ Faculty of Agronomic Science, University of Abomey-Calavi, Cotonou, Benin \\ ${ }^{3}$ Laboratory of Plant Biology, Department of Crop Science, Faculty of Agronomic Science, University of \\ Abomey-Calavi, Cotonou, Benin \\ Email: bokossakouessiv@yahoo.fr
}

Received 19 August 2014; revised 21 September 2014; accepted 23 October 2014

Copyright @ 2014 by authors and Scientific Research Publishing Inc.

This work is licensed under the Creative Commons Attribution International License (CC BY).

http://creativecommons.org/licenses/by/4.0/

(c) (1) Open Access

\section{Abstract}

In spite of the relevance of current studies on the importance of organic fertilizers such as animal manure in improving the health of ecosystems, little is known about the biochemical mechanisms affecting the availability of nutrients released from the organic fertilizer in water. A litter bag study during 6 weeks was carried out in pots containing 25 liters of water with $15 \mathrm{~g}$ of pig dejections as organic fertilizers. The experimental design was a completely randomized block design with three replications. The treatments consisted of dejections of pigs nourished with: recommended diet composition T1, partially improved diet with Azolla filiculoides T2, improved diet with Azolla filiculoides T3, improved diet with cereal bran T4. A control treatment without dejection (T0) was considered in the study for comparison purpose. Four pigs per type of diet were considered leading to 16 white landrace pigs of six months age followed for dejection collections. Strong release of nutrients for better yield for agro-fish system was obtained in the manure T1 with $\mathrm{NO}_{3}^{-}(10.85 \pm 0.00) \mathrm{mg} / \mathrm{L} ; \mathrm{NO}_{2}^{-}(0.011 \pm 0.00) \mathrm{mg} / \mathrm{L} ; \mathrm{PO}_{4}^{3-}(2.13 \pm 0.07) \mathrm{mg} / \mathrm{L}$ and $\mathrm{K}^{+}$ $(10.76 \pm 0.57) \mathrm{mg} / \mathrm{L} ; \mathrm{Ca}^{2+}(2.92 \pm 0.11) \mathrm{mg} / \mathrm{L}$ and $\mathrm{Mg}^{2+}(2.53 \pm 0.00) \mathrm{mg} / \mathrm{L}$ followed by manure $\mathrm{T} 3$ and $\mathrm{T} 4$ with high $\mathrm{N}$ content. The relatively low ratio $\mathrm{C} / \mathrm{N}(14.25)$ for $\mathrm{T} 1$ and (15.84) for $\mathrm{T} 3$ induced more nutrients releasing. This study showed an important $\mathrm{N}$ loss probably due to microorganism activities which fluctuate nutrient availability. Also significant correlations were noted between

${ }^{*}$ Corresponding author.

How to cite this paper: Bokossa, H.K.J., Saïdou, A., Sossoukpe, E., Fiogbé, D.E. and Kossou, D. (2014) Decomposition and Mineralization Effect of Various Sources of Pig Manure on Water Quality and Nutrients Availability for Agro-Fish System in Benin. Agricultural Sciences, 5, 1194-1206. http://dx.doi.org/10.4236/as.2014.512129 
the nutrient dynamics in water and physicochemical parameters showing the effect of abiotic factors on organic matter decomposition and mineralization which depend on microbial activities in water and pig manure composition.

\author{
Keywords \\ Pig's Diet, Manure, Fertilization, Physico-Chemical Microbial Water Properties, Nutrients \\ Availability
}

\title{
1. Introduction
}

The current population growth demands from the international community to increase and diversify agricultural and fisheries productivity. This can only be achieved through the improvement of crops and livestock by adopting more efficient farming techniques [1]. The recent decade has seen the growth of a particular attention to the issue of pollution from chemical fertilizers and pesticides [2], which remains the increase in production costs and significantly reduce farmers' incomes. In this context, manure with the organic matter they contain, are not only a guarantee for the physical, chemical and biological soil fertility but also the main pillars for achieving gains significant productivity [1]. Generally farmyard manure or composts are suggested as an alternative process for the management of these wastes [3]. Nitrogen release from organic wastes mineralization has been successfully tested in agriculture [3]-[7]. These authors concluded that, the supply of manure in agricultural land is an excellent way to recycle nutrients and organic matter to improve crop production. But according to [4], knowledge of nutrients release from the mineralization of organic manure is critical in regulating net ecosystem productivity, especially in nutrient-limited systems. In fact, controlling the rate of mineralization including biochemical mechanisms affecting the availability of nutrients released is essential for rigorous prediction quantities of organic fertilizers for rice-fish systems. $\mathrm{Lu}$ and $\mathrm{Li}$ [8] revealed that rice-fish farming systems constitute a unique agro-landscape across the world, especially in tropical and sub-tropical areas and the introduction of fish rearing to rice farming creates an integrated agro-ecological system practice. In that system, Haroon et al. [9] found that paddy yields were ranging $1.5-3.7 \mathrm{t} \cdot \mathrm{ha}^{-1} \cdot \mathrm{crop}^{-1}$ in rice-fish and $1.5-1.8 \mathrm{t} \cdot \mathrm{ha}^{-1} \cdot \mathrm{crop}^{-1}$ in rice-alone culture with insignificant differences between the years $(\mathrm{P}>0.05)$. It was also proved that, when the pigs were nourished with diet of high nutritive value such as Azolla filiculoides, it also improves the quality of dejection produced which could be used to feed fish and to supply nutrient to the crop considering wetland production system [10]. In such way, developing strategies to recycle nutrient from these residues especially those from livestock and pig in the context of Benin agriculture is a challenge. However, in Benin more than 518,600 pigs are breed with an increase of $3 \%$ of the livestock the last four years [11] [12] leading to an important quantities of dejection produced which are source of environmental pollution. Zooplankton productions systems based on the use of pig manures have been previously reported [13] but there is lack of knowledge on the biochemical mechanisms affecting the availability of nutrients released during the mineralization of organic fertilizers such as manure from pig fed with Azolla filiculoides and rice bran in wetland condition for fish and crop production system.

This paper reports the results of a study of pig dejection decomposition and nutrient mineralization in wetland condition using pots experiment. It aims to (i) evaluate the influence of diet on the nutritional quality of applied manure, (ii) evaluate the effect of the nutritional quality of different sources of pig manure on nutrient dynamics in wetland, (iii) determine the effect of abiotic parameters on nutrient availability in the water.

\section{Materials and Methods}

\subsection{Experimental Site}

The experiment was carried out on the site of the Laboratory of Research on Wetlands (LRW) Department of Zoology, Faculty of Science and Technique of University of Abomey-Calavi, Benin (Longitude E: 2²0'18.7"; Latitude $\left.\mathrm{N} 6^{\circ} 24^{\prime} 53.4^{\prime \prime}\right)$. This site is located at an altitude of $17 \pm 3 \mathrm{~m}$. The area is characterized by sub-equatorial climate with two rainy seasons (March to end of July and mid-September to November) and two dry seasons 
(August to mid-September and December to March). The rainfall pattern and temperature during the experiment is presented in Figure 1.

Azolla filliculoides an aquatic fern used to enrich the pigs diet was produced during two months (June to July 2013) in ponds located at the experimental site.

\subsection{Pigs Manure Collection and Process}

Pigs feeding and manure collection according to the types of diet served to the animal were carried out in the LRW pigsty located on the experimental site. The manures were daily collected and mixed according to the diet served to the pigs. Experiment on pigs' manure decomposition was carried out on the site of LRW. The dejections were collected from July $17^{\text {th }} 2013$ until sufficient quantity to carry out the experiment was obtained in $19^{\text {th }}$ August 2013. The dejections collected were dried at ambient temperature. About $50 \mathrm{~kg}$ of pig dejection were collected per types of diet given to the pigs. The diets given to the pigs were made based on result of Azolla filiculoides use from experiment carried out by Accodji et al. [11] and Djissou [14].

The treatment were manure collected from pigs nourished with: T1 (recommended diet composition: 15\% Azolla $+55 \%$ provender $+5 \%$ coconut copra $+5 \%$ oil palm $+5 \%$ soybean bran $+10 \%$ rice bran $+5 \%$ kitchen waste), T2 (partially improved diet with Azolla: 30\% Azolla $+65 \%$ rice bran $+5 \%$ oil palm), T3 (improved dietwith Azolla: 47.5\% Azolla $+47.5 \%$ rice bran $+5 \%$ oil palm), and T4 (improved diet with cereal bran: 15\% Azolla $+40 \%$ rice bran $+40 \%$ wheat bran $+5 \%$ oil palm). A control treatment without manure (T0) was considered in the study as comparison purpose. The experiment was carried out during six weeks (from 19 September to 25 October 2013).

In total, four pigs per type of diet were considered leading to 16 white landrace pigs of six months age followed for dejection collection. Instead of plastic containers clay jars were used for the pot experiment as they create fresh conditions like in the wetland. Tap water was used to create wetland condition in the jars.

\subsection{Experimental Design}

The experimental design was a complete randomized block with three replications. Manure bags used in this experiment were constructed from nylon mosquito net with a mesh size of $1 \mathrm{~mm}$. The nylon was tied $15 \mathrm{~g}$ of dejection and suspended in 25 liters of tap water representing $600 \mathrm{~g} / \mathrm{m}^{3}$ [3] and also adapted from litter-bags techniques [15]-[17].

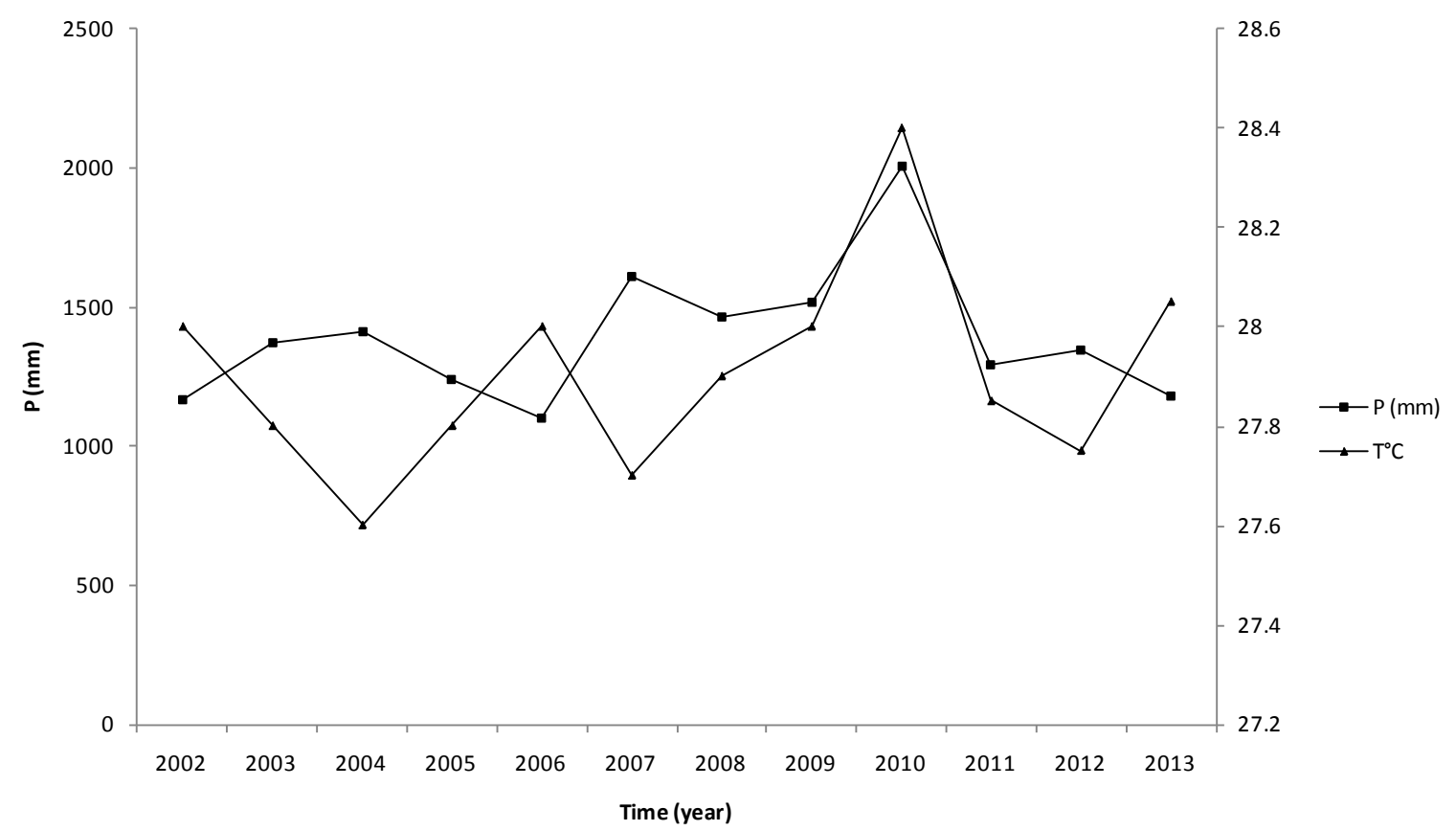

Figure 1. Rainfall pattern and temperature during the experiment. 
For each treatment (except the control), 12 bags with $15 \mathrm{~g}$ oven dried manure material were filled. Manure bags were randomly placed in the 12 clay jars of one lot to be sampled weekly. In total, 6 lots of 12 clay jars leading to 72 clay jars. A control (T0) consists of jars containing 25 liters of water without dejection in addition to jars containing water and dejection. Overall, 15 water samples were successively collected at 6, 12, 18, 24, 30 and 36 days and transported to the laboratory for the analysis. So for each sampling time, there were three manure bags per treatment.

\subsection{Manure and Water Analysis}

Analyses concerned firstly dejection quality after feeding and secondly water containing these dejections during mineralization process. Methods used for the dejection analysis were that described by NF EN 14082 norm [18]. The analyses were performed on: organic carbon (After drying, powder reduction and incineration at $550^{\circ} \mathrm{C}$ for $24 \mathrm{~h}$, the organic matter is determined by the difference between the treated sample and the mass of ash obtained assigned an empirical coefficient of 2.) The ash obtained after dissolution in $\mathrm{HCl}, 6 \mathrm{~N}$, after evaporation at $125^{\circ} \mathrm{C}$ gives a residue which, dissolved in $\mathrm{HNO}_{3}$ were used to measure $\mathrm{Ca}, \mathrm{Mg}, \mathrm{K}$ and $\mathrm{P}$ by spectrophotometric essay, total $\mathrm{N}$ using Kjeldahl digestion in a mixture of $\mathrm{H}_{2} \mathrm{SO}_{4}$ selenium method followed by distillation and titration, total P using AFNOR NFT 90-023, 1982 spectrophotometric assay after persulphate digestion in Kjeldahl flask method. Water sample collected were stored at the laboratory in a fridge at $4^{\circ} \mathrm{C}$ in order to assess enrichment with nutrient released during the mineralization process. Analyses included suspended solids, $\mathrm{NO}_{3}^{-}$, $\mathrm{NO}_{2}^{-}$and $\mathrm{NH}_{4}^{+}$. The suspended solids were measured using Standard NF EN 14082 method after water evaporation in an oven at $105^{\circ} \mathrm{C}$ for 24 hours. $\mathrm{NO}_{3}^{-}$using sodium salicylate method [19], nitrate ions in the presence of sodium salicylate form sodium paranitrosalicylate colored in yellow which is measured colorimetrically at a wavelength of $420 \mathrm{~nm}$. $\mathrm{NO}_{2}^{-}$using reagent of Zambely method [19], where ammonium ions in presence of sulfanilic acid and phenol form a yellow colored complex whose intensity is proportional to the concentration of $\mathrm{NO}_{2}^{-}$and the ions concentration is measured colorimetrically at a wavelength of $435 \mathrm{~nm} . \mathrm{NH}_{4}^{+}$by NESSLER method [19], ammonia in the presence of this reagent for reddish-brown color which is measured colorimetrically at a wavelength of $425 \mathrm{~nm}$. $\mathrm{PO}_{4}^{3-}$ (In strongly acidic solution, the ammonium molybdate reacts with the orthophosphate to form phosphoric acid molybdo reduced by amino acid reactive to form a blue compound capable for spectrophotometric assay at 700 and $880 \mathrm{~nm}$.)

$\mathrm{K}^{+}, \mathrm{Ca}^{2+}$ and $\mathrm{Mg}^{2+}$ content in water were determined with Atomic Absorption Spectrophotometer. Temperature and dissolved oxygen were measured in situ using Oxythermometer brand OXI 197i-N27455, the conductivity using conductivimeter brand N27444-197i, and pH with pH meter 197i brand-N27499.

\subsection{Method of Statistical Analysis}

The variance analysis test followed by the homogeneity test of Student-Newman-Keuls at the 5\% was performed with the SAS 9.2 software. These tests were performed after inspection of the normality and homoscedasticity conditions of variance, to compare the means of physico-chemical data. Also using Minitab, the Pearson correlation coefficient was used to determine possible correlations between the temperature, dissolved oxygen, $\mathrm{pH}$, conductivity and nutrient dynamics.

\section{Results}

\subsection{Diets and Pig Manure Chemical Composition}

The chemicals characteristics of pigs' manures used for the experiment are presented in Table 1. It appears from the results that carbon and nitrogen content in the manure collected from pigs nourished with improved diet with Azolla (T3) significantly $(\mathrm{P}<0.05)$ increase by 1.2 and 1.3 times compared with that collected from pigs nourished with the recommended diet composition (T1). In general for carbon, one can rank the manures richness according: $\mathrm{T} 3>\mathrm{T} 2>\mathrm{T} 1>\mathrm{T} 4$ and $\mathrm{T} 3>\mathrm{T} 1>\mathrm{T} 4>\mathrm{T} 2$ for nitrogen content. These results lead to a lowest $\mathrm{C} / \mathrm{N}$ ratio for treatment $\mathrm{T} 3$ while the highest $\mathrm{C} / \mathrm{N}$ ratio was obtained with $\mathrm{T} 1$ and $\mathrm{T} 4$.

The manure collected from pigs nourished with recommended diet composition (T1) presents significantly higher $\mathrm{P}$ content compared with that collected from treatment T2, T3 and T4 (Table 1). The addition of Azolla in the diet seems to decrease significantly by 1.1 and $1.3 \mathrm{P}$ content in the treatment T3 and T2 respectively compared with T1. Furthermore, K, Ca and Mg concentrations were high in the manure T1 compared with the 
Table 1. Average value ( \pm standard errors) of the chemical characteristics of pigs' manures regarding the composition of the diets (T1 = Manure of pigs nourished with recommended diet composition; T2 = manure of pigs nourished with diet partially improved with Azolla; T3 = manure of pigs nourished with diet improved with Azolla; T4 = manure of pigs nourished with diet improved with cereal bran) used to feed the animal.

\begin{tabular}{ccccccc}
\hline \multirow{2}{*}{ Treatment } & \multicolumn{5}{c}{ Nutrient content $(\mathrm{g} / \mathrm{kg})$} \\
\cline { 2 - 7 } & $\mathrm{C}$ & $\mathrm{N}$ & $\mathrm{P}$ & $\mathrm{K}$ & $\mathrm{Ca}$ & $\mathrm{Mg}$ \\
\hline T1 & $261.78 \pm 0.00 \mathrm{c}$ & $18.37 \pm 0.00 \mathrm{~b}$ & $5.40 \pm 0.00 \mathrm{a}$ & $8.21 \pm 0.00 \mathrm{a}$ & $8.66 \pm 0.00 \mathrm{a}$ & $2.77 \pm 0.00 \mathrm{a}$ \\
T2 & $274.54 \pm 0.00 \mathrm{~b}$ & $13.89 \pm 0.00 \mathrm{~d}$ & $4.06 \pm 0.00 \mathrm{~d}$ & $3.64 \pm 0.00 \mathrm{c}$ & $6.08 \pm 0.00 \mathrm{c}$ & $1.95 \pm 0.00 \mathrm{c}$ \\
T3 & $325.68 \pm 0.00 \mathrm{a}$ & $24.64 \pm 0.00 \mathrm{a}$ & $4.86 \pm 0.00 \mathrm{~b}$ & $3.36 \pm 0.00 \mathrm{~d}$ & $6.28 \pm 0.00 \mathrm{~b}$ & $2.63 \pm 0.00 \mathrm{a}$ \\
T4 & $241.24 \pm 0.00 \mathrm{~d}$ & $15.23 \pm 0.00 \mathrm{c}$ & $4.62 \pm 0.00 \mathrm{c}$ & $4.33 \pm 0.00 \mathrm{~b}$ & $5.79 \pm 0.00 \mathrm{~d}$ & $2.07 \pm 0.00 \mathrm{~b}$ \\
CV (\%) & 11.79 & 24.01 & 10.61 & 41.73 & 18.16 & 15.57 \\
\hline
\end{tabular}

Note: means followed by the same letter are not significantly different $(\mathrm{P}>0.05)$ according to the Student Newman-Keuls test.

other treatments. However, significant decrease by 2.3, 2.4 and 1.9 were noticed with $\mathrm{K}$ concentration in the manures respectively with treatments $\mathrm{T} 2$, T3 and T4 compared with T1. The decrease is less (1.4 for treatments T2 and T3 and 1.5 with T4 compared with treatment T1) with Ca content in the manures. Concerning Mg content, manure collected from pigs' nourished with improved diet with Azolla did not vary compare with that from pigs nourished with recommended diet composition. However, significant decrease by 1.4 and 1.3 in $\mathrm{Mg}$ content in the manure is noticed with treatments T2 and T4 compared with that of pigs nourished with recommended diet composition (treatment T1). The coefficient of variation calculated for all treatments is somewhat elevated for $\mathrm{N}$ and $\mathrm{K}(\mathrm{CV}>20)$ and somewhat lower for $\mathrm{P}, \mathrm{Ca}, \mathrm{Mg}$ and $\mathrm{C}(\mathrm{CV}<20)$ revealing the difference in composition manure and in conjunction with the chemical composition of the tested diets. We can conclude that nutrients content in the manure depends on the chemical composition of the diet used to feed the animals.

\subsection{Water Quality and Nutrient Dynamics}

\subsubsection{Physical and Chemical Parameters Measured in Situ}

Change in temperature (Figure 2(c)), dissolved oxygen (Figure 2(a)), conductivity (Figure 2(d)), and Ph (Figure 2(b)) during the 36 days of experiment is depicted in Figure 2. In general, the values of the water temperature fluctuate between $25.90^{\circ} \mathrm{C}$ and $33.77^{\circ} \mathrm{C}$ approximately. The values observed are similar in all treatments and vary according to the weeks of experiment. However, there is a drop in global temperature after a week of fertilization in all treatments and increase during the 3rd and 6th week. These temperatures observed are those of mesophilic microorganisms therefore support the biodegradability of organic matter in pig manure. The temperature rise observed the 3rd and 6th week shows activation of metabolic reactions of nutrients released by microorganisms. Dissolved oxygen affects life in ecosystems. The average values of dissolved oxygen registered during the experiment are between $8.36 \mathrm{mg} / \mathrm{L}$ and $16.57 \mathrm{mg} / \mathrm{L}$. However, in the 3rd and 6th weeks a decrease in the concentration of dissolved oxygen in all treatments was observed; this can be correlated with the increase in temperature observed in the third and sixth week of experimentation. In fact, aerobic microorganisms whose metabolic activity is activated by the rise in temperature consume then enough oxygen for faster degradation of organic matter. $\mathrm{pH}$ values at the start of experiment were low and indicate relatively acidic water (5.13). These values range 5.13 to 8.14 at the end of experiment, whereas in the control treatment $\mathrm{T} 0$, the $\mathrm{pH}$ remained relatively low. The contribution of manure resulted in a gradual increase in the $\mathrm{pH}$ which reached 8.14 especially in T4. This indicate a propensity to alkalinity in water containing pig manure mainly due to a release of $\mathrm{NH}_{3}$ from $\mathrm{NH}_{4}^{+}$in the area during pig manure mineralization in the water. Water conductivity is a global but rough parameter to estimate water mineralization. Except treatment $\mathrm{T} 0(90.98 \mu \mathrm{S} / \mathrm{cm})$ where conductivity values were low and constant, those observed in T1 to T4 increased from the first to the sixth week. Generally, water conductivity in jars range $40.66 \mu \mathrm{S} / \mathrm{cm}$ to $174,93 \mu \mathrm{S} / \mathrm{cm}$ reflecting progressive mineralization of water due to the activity of pig manure decomposition by microorganisms

\subsubsection{Nutrient Dynamics in Water ( $\mathrm{mg} / \mathrm{L})$}

Nutrient dynamics during the experiment are presented in Figure 3. $\mathrm{NO}_{2}^{-}$rates (Figure 3(a)) in the different treatments were increased over time with variations ranging between $(0.003 \pm 0.00)$ and $(0.11 \pm 0.00) \mathrm{mg} / \mathrm{L}$ ob- 


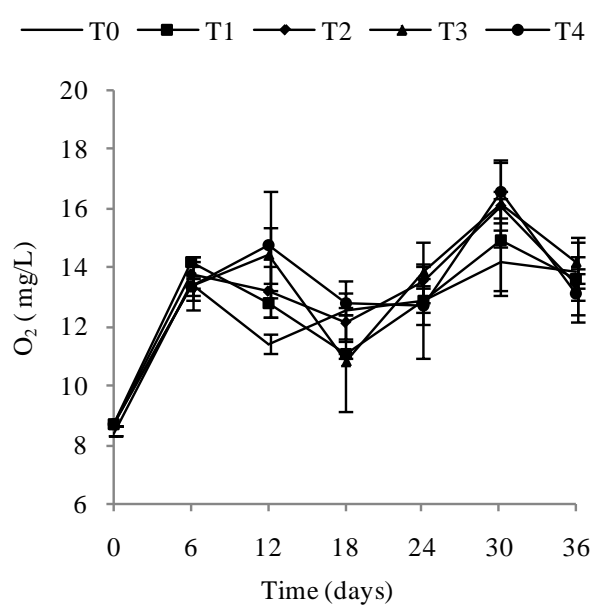

(a)

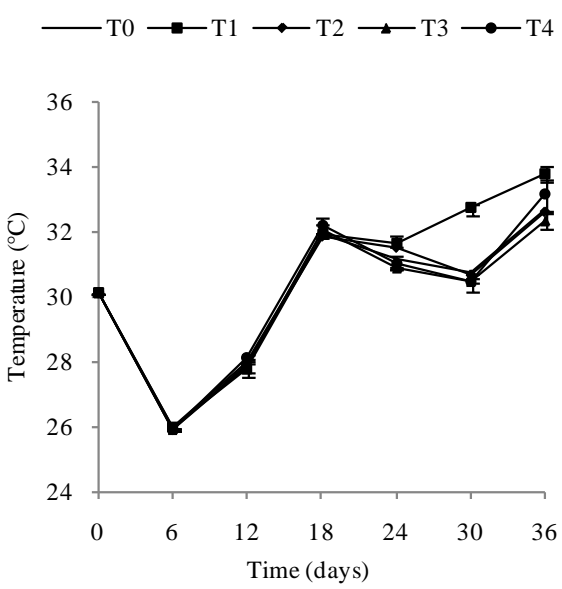

(c)

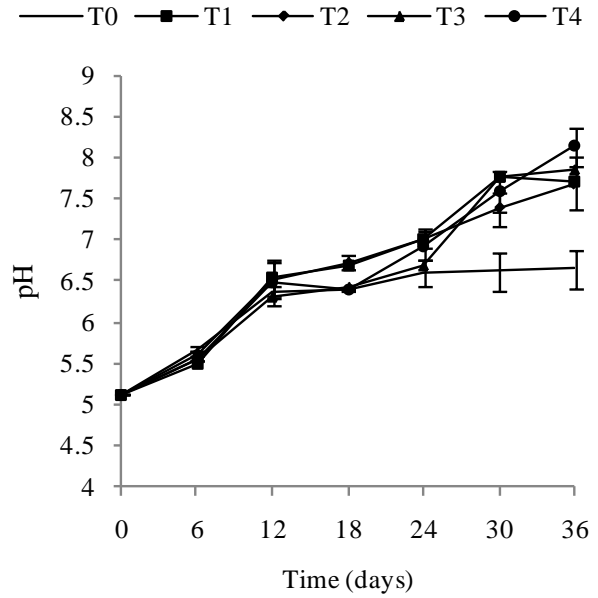

(b)

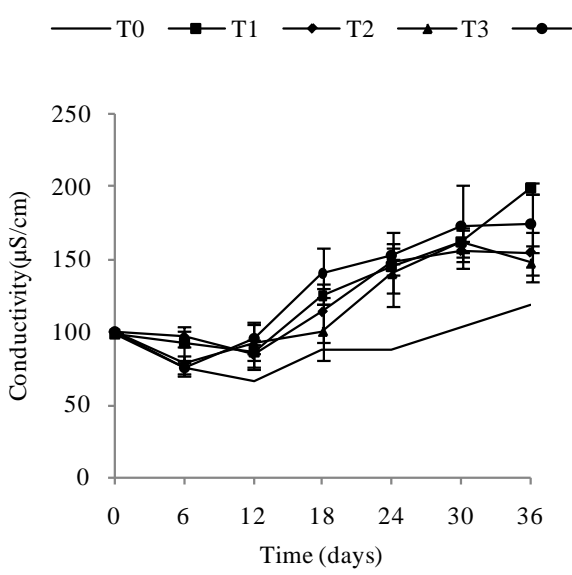

(d)

Figure 2. Change in temperature, dissolved oxygen, conductivity, and $\mathrm{pH}$ during the 36 days of experiment. (a) Change in Dissolved Oxygen (mg/L) during 36 days of experiment; (b) Change in $\mathrm{pH}$ during 36 days of experiment; (c) Change in Temperature $\left({ }^{\circ} \mathrm{C}\right)$ during 36 days of experiment; (d) Change in conductivity $(\mu \mathrm{S} / \mathrm{cm})$ during 36 days of experiment.

tained with T4 during the fourth week. Also there is a decrease of nitrite content in treatments T1 to T4 during the 3rd and 6th weeks. These variations observed are related to the activities of micro-organisms in the water that influences nitrogen availability with $\mathrm{NO}_{2}^{-}$which are more or less unstable.

Nitrates (Figure 3(b)) are the most stable form of the nitrogen in the water from the nitrification and organic nitrogen. During the test, the values of the nitrates content are between $(6.04 \pm 0.00) \mathrm{mg} / \mathrm{L}$ and $(22.95 \pm 3.19)$ $\mathrm{mg} / \mathrm{L}$ with a high value observed in T1 with $(22.95 \pm 3.19) \mathrm{mg} / \mathrm{L}$ after five weeks fertilization. Decreases levels were observed during the third and sixth weeks. Indeed, as the temperature increases, the biochemical reactions are activated and result in a loss of $\mathrm{NH}_{3}$ by transformation of nitrogen or denitrifying bacteria where the decrease observed in the third and sixth weeks. It was noted that the low value recorded at the control treatment T0 is due to the fact that this treatment has received no manure.

The values of $\mathrm{NH}_{4}^{+}$content (Figure 3(c)) recorded during the experiment range between $(0.04 \pm 0.00) \mathrm{mg} / \mathrm{L}$ and $(0.5 \pm 0.20) \mathrm{mg} / \mathrm{L}$. Increases were observed in T1 to T4 with a decline in the 3rd and 6th weeks of fertilization. The highest values are recorded at T1 and T3. In manure, there is a balance between the $\mathrm{NH}_{4}^{+} / \mathrm{NH}_{3}$ form; This is related to the equilibrium constant which can be favorable to a massive loss of nitrogen as ammonia gas or favorable to storage in water as $\mathrm{NH}_{4}^{+}$. The process of ammonia volatilization is the transfer of ammonia gas in the immediate atmosphere from ammonia in manure decomposing in water. The factors responsible for nitrogen losses observed at week 3 and week 6 are therefore related to temperature, the enzymatic activity of organ- 


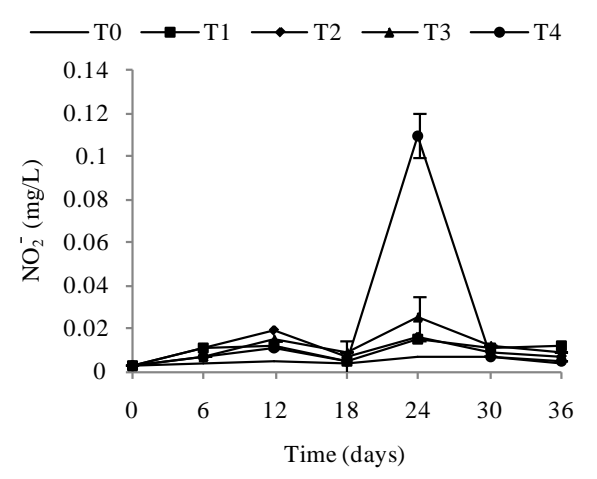

(a)

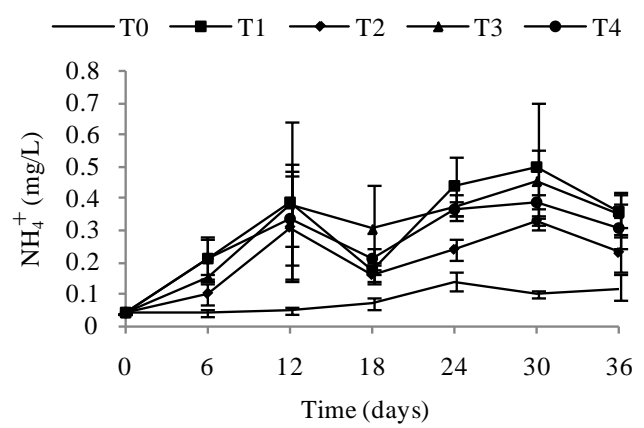

(c)

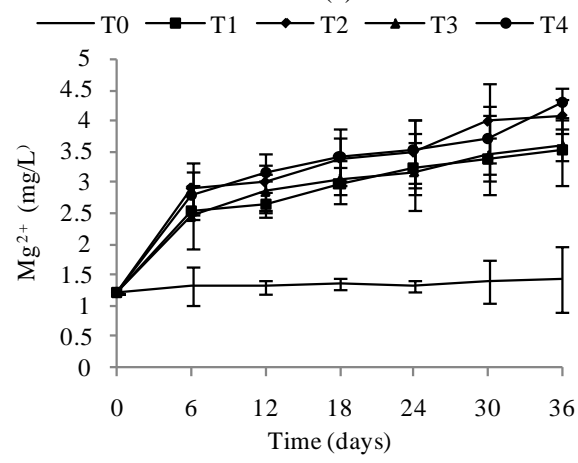

(e)

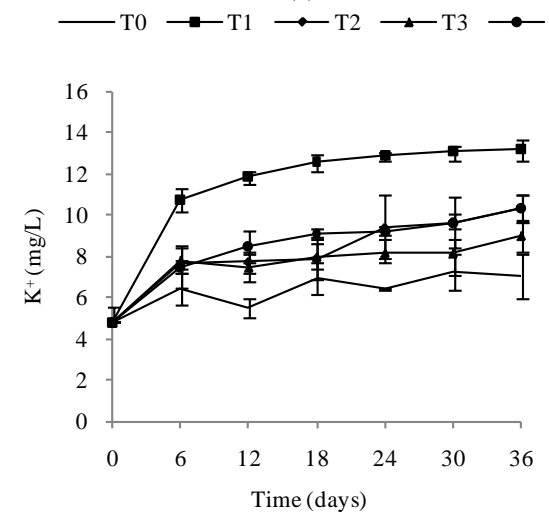

(g)

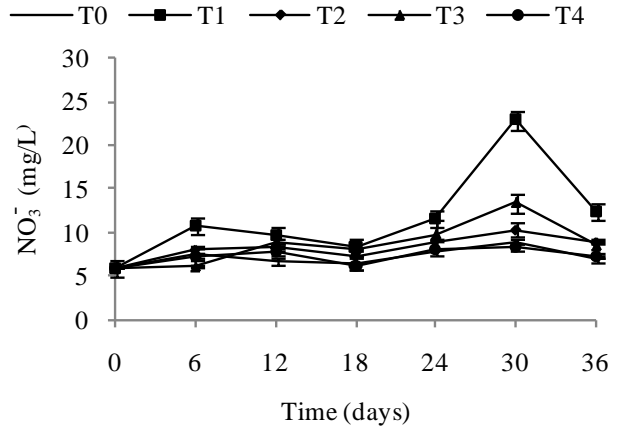

(b)

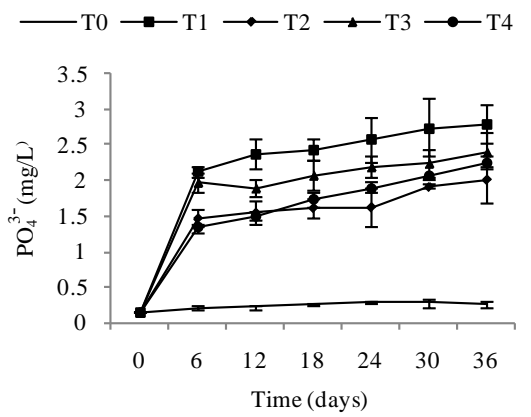

(d)

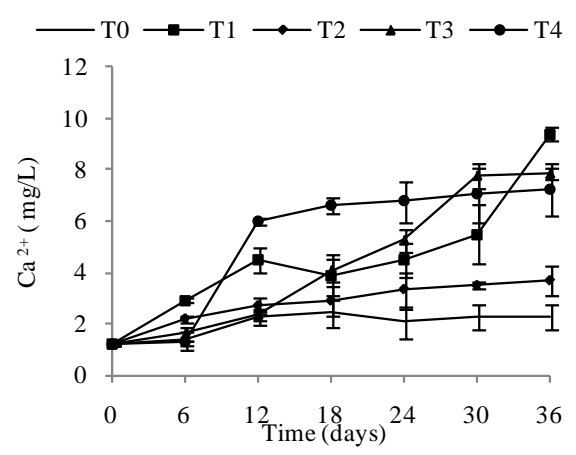

(f)

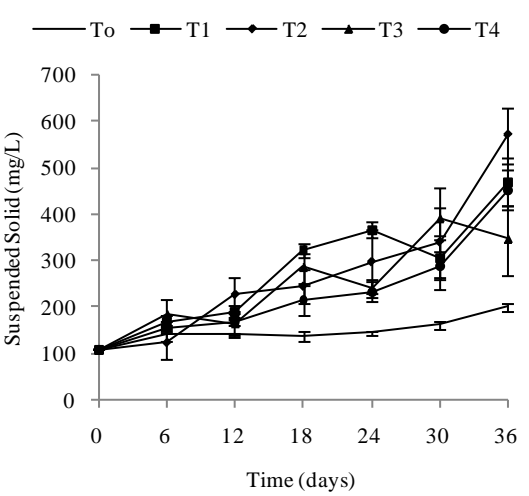

(h)

Figure 3. Variation of the nutrient $\left(\mathrm{NH}_{4}^{+}, \mathrm{NO}_{2}^{-}, \mathrm{NO}_{3}^{-}, \mathrm{PO}_{4}^{3-}, \mathrm{K}^{+}, \mathrm{Ca}^{2+}\right.$ and $\left.\mathrm{Mg}^{2+}\right)$ and Suspended solids in water during the 36 days of experimentation. (a) Change in $\mathrm{NO}_{2}^{-}$content $(\mathrm{mg} / \mathrm{L})$; (b) Change in $\mathrm{NO}_{3}^{-}$content $(\mathrm{mg} / \mathrm{L}$ ); (c) Change in $\mathrm{NH}_{4}^{+}$content (mg/L); (d) Change in $\mathrm{PO}_{4}^{3--}$ content (mg/L); (e) Change in $\mathrm{Mg}^{2+}$ content (mg/L); (f) Change in $\mathrm{Ca}^{2+}$ content $(\mathrm{mg} / \mathrm{L}) ;(\mathrm{g})$ Change in $\mathrm{K}^{+}$content $(\mathrm{mg} / \mathrm{L})$; (h) Change in Suspended solid content $(\mathrm{mg} / \mathrm{L})$ 
isms present in the water, the $\mathrm{pH}$ and properties of manure in water.

The values of the $\mathrm{PO}_{4}^{3-}$ content (Figure 3(d)) recorded during the experiment were between $(0.14 \pm 0.00)$ $\mathrm{mg} / \mathrm{L}$ and $(2.8 \pm 0.26) \mathrm{mg} / \mathrm{L}$ with a regular growth especially after one week fertilization. Values were constant in T0 $(0.2 \pm 0.00) \mathrm{mg} / \mathrm{L})$ during the experiment. The rapid increase in the concentration of $\mathrm{PO}_{4}^{3-}$ (from T1 to T4) in the first week of experiment indicates a labile fraction of organic matter. From the second week to the end of the experiment, a readily degradable organic fraction was released by microorganisms in manure. The values of the $\mathrm{K}^{+}$content (Figure $3(\mathrm{~g})$ ) recorded during the experiment were between (4.82 \pm 0.00$)$ and (13.18 \pm 0.52 ) $\mathrm{mg} / \mathrm{L}$. These values from T1 to T4 increased with a high rate at the T1. The differences between treatments were not significant $(\mathrm{P}>0.05)$.The rapid increase in the $\mathrm{K}^{+}$content during the first week experience indicates a rapidly mineralizable labile fraction of organic matter and from the second week to the end of the experiment, a readily degradable fraction by resistant microorganisms in manure. The contents of $\mathrm{Mg}^{2+}$ (Figure 3(e)) increased during the experiment and ranged from $(1.21 \pm 0.00) \mathrm{mg} / \mathrm{L}$ and $(4.28 \pm 0.96) \mathrm{mg} / \mathrm{L}$. Linear growth is obtained in all treatments except the control treatment T0 with a maximum of $(4.28 \pm 0.96) \mathrm{mg} / \mathrm{L}$ at the T4 treatment. Pig manure fed Azolla filliculoides, rice bran and wheat bran enrich the water with nutrients $\mathrm{K}^{+}$and $\mathrm{Mg}^{2+}$. A significant increase in calcium is observed in different treatments during the experiment and these values are between $(1.20 \pm 0.00)$ and $(9.41 \pm 0.30) \mathrm{mg} / \mathrm{L}$. There were a remarkable increase of $\mathrm{P}, \mathrm{Ca}, \mathrm{Mg}$ and $\mathrm{K}$ in $\mathrm{T} 1$ after five weeks of treatment fertilization compared to others treatments. The ratio of suspended solids in the stored treatment T0 is much lower than that obtained in the treatments T1 to T4. The rate of suspended solids has been a gradual increase through the different treatments. It reflects a gradual release of mineral elements from organic pig manure. The temperature fluctuates between $30^{\circ} \mathrm{C}$ and $33^{\circ} \mathrm{C}$ reflecting the climatic conditions during experimentation period. With regard to suspended solids in the water, they present a remarkable increase between the beginning and end of the experiment on all treatments. Diet with high content of Azolla filliculoides (T3)'s manure release more suspended solids which were 1.4, 1.1 and 1.3 times higher than T4, T2 and T1 respectively.

\subsubsection{Correlations between in Situ Measured Parameters and Nutrient Dynamics in Water}

Abiotic parameters including $\mathrm{pH}$, conductivity, temperature and dissolved oxygen have strongly influenced the dynamics of nutrient released in the water during the mineralization process of manure from pig mainly fed with Azolla filiculoides and rice bran. Thus according to the Pearson correlation test, the $\mathrm{pH}$ is correlated with the concentration of $\mathrm{NO}_{3}^{-}\left(\mathrm{P}<0.05, \mathrm{r}^{2}=53.9\right)$ and very significantly correlated with each of the following nutrients $\mathrm{NH}_{4}^{+} \quad\left(\mathrm{P}<0.0001, \mathrm{r}^{2}=73\right), \mathrm{PO}_{4}^{3-} \quad\left(\mathrm{P}<0.0001, \mathrm{r}^{2}=65.7\right), \mathrm{K}^{+}\left(\mathrm{P}<0.0001, \mathrm{r}^{2}=67.7\right), \mathrm{Ca}^{2+}(\mathrm{P}<0.0001$, $\left.\mathrm{r}^{2}=79\right)$ and $\mathrm{Mg}^{2+}\left(\mathrm{P}<0.05, \mathrm{r}^{2}=74.8\right)$. The dissolved oxygen showed a significant correlation with $\mathrm{NO}_{3}^{-}(\mathrm{P}<$ $\left.0.05, \mathrm{r}^{2}=50.7\right)$ and high significant with $\mathrm{NH}_{4}^{+} \quad\left(\mathrm{P}<0.0001, \mathrm{r}^{2}=65.7\right), \mathrm{PO}_{4}^{3-} \quad\left(\mathrm{P}<0.0001, \mathrm{r}^{2}=56\right)$ and $\mathrm{Mg}^{2+}$ $\left(\mathrm{P}<0.0001, \mathrm{r}^{2}=66.6\right)$. Concerning the conductivity, it was significantly correlated with $\mathrm{NO}_{2}^{-}, \mathrm{NH}_{4}^{+} \mathrm{NO}_{3}^{-}$at $5 \%$. Also a highly significant correlation was found between the conductivity and the $\mathrm{Ca}^{2+}$ levels $\left(\mathrm{P}<0.0001, \mathrm{r}^{2}\right.$ =62.9), and $\mathrm{Mg}^{2+}\left(\mathrm{P}<0.0001, \mathrm{r}^{2}=62.7\right)$.

Indeed, the biochemical mechanisms of degradation of organic matter depend on physical and chemical conditions of the environment. The lower rate of dissolved oxygen in the $3^{\text {rd }}$ and $6^{\text {th }}$ week coincid with the increase of temperature reflecting a high decomposition activity of aerobic bacteria that induce a large release of nutrients $\mathrm{NO}_{3}^{-}, \mathrm{NH}_{4}^{+}, \mathrm{PO}_{4}^{3-}, \mathrm{Mg}^{2+}, \mathrm{K}^{+}$and $\mathrm{Ca}^{2+}$. The release of high concentration of $\mathrm{NH}_{4}^{+}$in the water changes the degree of dissociation of $\mathrm{NH}_{4}^{+} / \mathrm{NH}_{3}$ which becomes favorable to a massive release of $\mathrm{NH}_{3}$ with the consequent of increase of $\mathrm{pH}$ which is correlated with nutrient released by pig manure. It is the same for the conductivity which increased over time in proportion to the levels of nutrient. The decomposition of pig manure already rich in microorganisms facilitated by water leads to a faster release of mineral elements influence the overall content of nutrients and consequently the conductivity.

In total, the release of nutrients contained in the manure of pigs fed on Azolla filiculoides and rice bran was modulated by abiotic parameters namely dissolved oxygen, $\mathrm{pH}$, conductivity and temperature in the aquatic environment.

\section{Discussion}

\subsection{Influence of the Tested Diets on Manure Fertilizer Quality}

Food is an essential parameter of the composition of the manure. Approximately 60\% - 80\% of the nitrogen and 
phosphorus ingested are not absorbed by the animal and about $90 \%$ for potassium [20].

From the results obtained, the nutritional quality of manure varies significantly from one treatment to another. This is due to the composition of the diets and to the digestibility of applied rations for monogastric such as pigs. According to Corpen [21], diet and discharge quality depends of physiological state as required for pig metabolism. The standard reference for nitrogen rejection sow is $17.50 \mathrm{~kg} / \mathrm{sow} /$ year, post weaning $0.44 \mathrm{~kg} / \mathrm{pig}$ fattening phase, $3.25 \mathrm{~kg} / \mathrm{pig}$. The high levels of nitrogen in manure (T3) are related to the high content of Azolla in this regime. Also, the differences between manure composition are related to the nature of the raw material which was used: Azolla filiculoides and rice bran at various doses. This confirm the results of Faure [22] which focused with regard to protein content, that the yield of digestion vary considerably from raw materials, and by the variety for the same raw material. Others factors responsible for the variability in the quality of manure were cited such as trypsin inhibitors, lectins and tannins responsible for the low digestibility of certain varieties of peas [23].

Thus, the high rate of nitrogen released by the pig in the T3 can be explained by the low digestibility of the ingredients as Azolla filiculoides in the ration which is highly rich in fiber and lignin readily degradable. The $\mathrm{C} / \mathrm{N}$ ratios recorded in $\mathrm{T} 1$ to $\mathrm{T} 4$ are well above the $\mathrm{C} / \mathrm{N}$ ratio found in pig slurry whose value is 4 [24]. This difference could be explained by the composition of the diet applied to feed pigs.

\subsection{Quality Effects of Manure on the Enrichment of Water in Nutrients (N, P, K, Ca and Mg)}

During the decomposition of pig manure, the water temperature is an important factor not only for organic production but also for solubility gases such as oxygen [25]. Thus, the low value of the temperature observed after one week of fertilization is due to aeration of the area with oxygen. In fact, during this week of fertilization microbial activity is much slower compared to the 3rd and 6th where it is faster. Basic pH values (8.14) obtained at the end of the experiment reflecting an enrichment of the area in $\mathrm{NH}_{3}$ are contrary to the values of $\mathrm{pH}$ acids obtained by Brault [26] due to the degradation of organic substances. This difference could be explained by the environmental climatic conditions. However, the $\mathrm{pH}$ values recorded during these experiments are compatibles for fish farming which allows a value between 6.5 and 9 [27].

High levels of suspended solids matters and stored water conductivity in T1 to T4 are due to the high release of nutrient in the area and confirm the results of Belghiti et al. [25] who proved the mineralization effect on water mineral contents. For good manure, organic matter decomposition process is performed by heterotrophic bacteria which consume dissolved oxygen to release the nutrients such as ammonium, nitrite, nitrate and phosphate and carbon dioxide [28] The values recorded for nitrites during different sampling campaigns are in accordance with the optimum value required $0.1 \mathrm{mg} / \mathrm{L}$ [29] for aquaculture water. However, high level of nitrites (1.11 mg/L) obtained with T4 after 4 weeks of fertilization might be due to physico-chemical and biological process taking place in this environment [30]. Indeed, during the degradation process of organic matter by microorganisms there is an ammonia oxidation or reduction of the nitrate which induce a release of nitrous ions in the area. This could justify the findings observed in all the treatments except, To at the $3^{\text {rd }}$ and 6th week of experiment in which there has been a substantial decline in the rate of nitrogenous nutrients in fertilized water based on pig waste level. As for nitrates, these values are much higher than the standard set for surface water is 0.1 $\mathrm{mg} / \mathrm{L}$ for freshwater aquaculture [31].

High nitrate levels in treatments T1 to T4 could be explained by the significant degradation of organic matter in the area under the influence of microorganisms [32]. As nitrates proceed from the nitrification of nitrogen in pig waste [28], ammonium is a mineral which process usually results on an incomplete degradation of organic matter [28]. This could justify the fluctuating values nitrogen during the experiment where organic matter is gradually degraded. It is noted that the ammonium also appears in the area from the conversion of nitrates. It could also be noted that the different nitrogen forms and their evolution in ecosystems depend on biological activity, pedo-climatic conditions [33].

$\mathrm{PO}_{4}^{3-}$ concentrations obtained in the different treatments during the experiment showed a linear increase with a maximum of $2.80 \mathrm{mg} / \mathrm{L}$; that proves fertilizing water with pig manure represent a favorable environment for aquaculture [20]. However, high concentrations of ortho phosphate recorded in all treatments after one week of fertilization are probably due to rapid mineralization of labile fraction of pig manure under the influence of environmental temperature. Temperature plays an important role in the solubility of salts in water [34]. The significant level of $\mathrm{K}^{+}$in the fertilized area inform about the presence of the main mineral like nitrogen, phosphorus, 
oxygen, hydrogen and carbon [28]. The presence of $\mathrm{Ca}^{2+}$ and $\mathrm{Mg}^{2+}$ with significant levels especially in $\mathrm{T} 1$, also provide information on the rate of salts present in the areas [35] and then explain the increase of the water conductivity from the first test period to the end.

\subsection{Correlations between Parameters Measured in Situ and Nutrient Dynamics in Water}

According to our results, the Pearson correlation test revealed an interaction between abiotic parameters such as $\mathrm{pH}$, conductivity, dissolved oxygen, temperature and nutrient dynamics in water containing pig manure during mineralization. In spite of the increase in the content of nitrogenous nutrients throughout the experiment, significant nitrogen losses were recorded for all treatments particularly during the third and sixth weeks of experimentation, periods corresponding to lower rate of dissolved oxygen and an increase in temperature. Many authors showed the influence of abiotic physico-chemical parameters on the dynamics of nutrients in the water. Thus, according to Hafiane et al. [36], hot weather leads to increased net loss of nitrogen as $\mathrm{NH}_{3}$. In the same way, Dovonou et al. [37] prove that because $\mathrm{NH}_{4}{ }^{+}$proceed from the decomposition of excreta, it pass to gas form and lead to an elevation of $\mathrm{pH}$. This loss of nitrogen observed at the 3rd and $6^{\text {th }}$ weeks in $\mathrm{NH}_{3}$ corresponds to a transfer of ammonia gas present in the manure in the immediate atmosphere [38]. Indeed, according to the author, process of volatilization varies with the $\mathrm{NH}_{4}{ }^{+}$concentration in the manure, the enzyme activity, the $\mathrm{pH}$, the temperature, and the slurry properties. Complementary to this author, [39] describes in fact, an equilibrium which exists between the concentrations of $\mathrm{NH}_{4}^{+}$and $\mathrm{NH}_{3}$; since the concentrations of $\mathrm{NH}_{3}$ increases, more $\mathrm{NH}_{4}^{+}$is transformed in $\mathrm{NH}_{3}$ to maintain balance within the slurry. This balance depends on $\mathrm{pH}$, as confirmed by the current study result; a basic $\mathrm{pH}$ is consistent with the predominance of $\mathrm{NH}_{3}$ form. These results are also in accordance with those of Moal et al. [39]; Kemarrec et al. [40] which showed that the temperature affects the degree of dissociation of $\mathrm{NH}_{4}^{+} / \mathrm{NH}_{3}$, indicate that the increase of the diffusion of $\mathrm{NH}_{3}$ is proportional to the temperature. Similarly Corpen [21], found about equilibrium $\mathrm{NH}_{4}^{+} / \mathrm{NH}_{3}$, if the concentration of $\mathrm{NH}_{4}^{+}$increases, the $\mathrm{pH}$ decreases. Reversely, with regard to the dynamics of ammonium, the current results did not match with those reported by Brault [26] who found that the degradation of organic substances leads to a general tendency to acidify the area as a result of rapid fermentation; this is certainly justified by the nature of the material being studies but also anoxic conditions of his work. Regarding the dissolved oxygen, the current study showed that dissolved oxygen levels highly correlated with the release of nutrients. The decrease in dissolved oxygen observed at $3^{\text {rd }}$ and $6^{\text {th }}$ weeks of experiment is correlated with an increase of temperature during the same period. According to Corpen [21], oxygen is influenced by two parameters including the water temperature and its conductivity. This aspect was studied by Hassan et al. [41], which showed that the concentration of dissolved oxygen is a key parameter for the activity of bacteria that provide the degradation of organic matter. In the same way, Belghiti et al. [25]; Rodier [42]; Cornaz [28] concluded that the oxygen is consumed by the chemo-synthetically mineralizing microorganisms and facilitate the release of nutrient in natural waters. Rapid degradation observed in the case of this study is justified since Laferrière [43] and Salanitro [44] attested the presence of 3 to $6 \times 10^{10}$ bacteria/g in the pig slurry and these micro-organisms play a key role in the mineralization rate of these wastes. The variations in the dissolved oxygen content correlated with the increase of the conductivity across the treatment were observed by Belghiti et al. [25] and Rodier [42] who showed that the conductivity values of water depends on loads mineral matter in water and therefore the total quantity of dissolved salts in the water. Also the nature of the organic material could influence the rate of dissolved oxygen. Total mineralization of pig manure including T1 to T4 which released more nutrients $\mathrm{N}, \mathrm{P}, \mathrm{K}, \mathrm{Ca}$ and $\mathrm{Mg}$, have increased their concentrations but a significant loss of nitrogen nutrients was noted. We suggest in fact, for recovery any agricultural and fishery purpose, it requires a periodic supply of split pig manure or addition of nitrogen fertilizer to supplement losses of nitrogen nutrients. Although a relatively large amount of nutrients in manure are observed at the beginning, abiotic factors such as $\mathrm{pH}$, temperature, conductivity and dissolved oxygen modulate the release rate of these nutrients.

\section{Conclusion}

The studies on the decomposition of pig manure fed on with different foods based on Azolla filiculoides and rice bran prove that the treatments T1 containing Azolla filiculoides, provender and rice bran showed rapid mineralization because of their relative low $\mathrm{C} / \mathrm{N}$ ratio. The composition of pig dejection varies from one treatment to another because of the composition of the diet applied. The treatments T2 and T3 which contained respectively 
$30 \%$ and $47.5 \%$ of Azolla (aquatic plant rich in nitrogen) in their food release significant rate of nitrogen in the manure. The $\mathrm{C} / \mathrm{N}$ ratio in the treatment $\mathrm{T} 2$ slows the rate of mineralization of the organic material and thereby a very small quantity of nutrients is available in the water while those reports in the treatments T1, T3 and T4 were respectively $14,25,13.22$ and 15.85 .

The water quality varies according to the composition of the animal dejection, but it also depends on the duration of fertilization, the abiotic parameters such as $\mathrm{pH}$, temperature, conductivity and dissolved oxygen which modulate microorganism activities in the manure then nutrient availability for agro-fish system.

\section{Acknowledgments}

We express our gratitude to the Scientific Council of the University of Abomey-Calavi, which funded the project untitled "Optimization of Agricultural Production Integrated System without Inputs (OPASISI)" in which this research work has been undertaken.

\section{References}

[1] FAO (Food and Agriculture Organization) (2006) Utilisation des engrais par culture au Maroc. Première édition (Rome), $73 \mathrm{p}$.

[2] Pilar, F., Castellar, I. and Navarro, J. (2005) Nitrate Leaching in Pepper Cultivation with Organic Manure and Supplementary Additions of Mineral Fertilizer. Communications in Soil Science and Plant Analysis, 36, 2889-2899. http://dx.doi.org/10.1080/00103620500306072

[3] Amadji, L.G., Saidou, A. and Chitou, L. (2009) Recycling of Organic Residues in Compost to Improve Coastal Sandy Soil Properties and Cabbage shoot In Benin. International Journal of Biological and Chemical Sciences, 3, 192-202.

[4] Cordovil, C.M.S., Cabral, F. and Coutinho, J. (2007) Potential Mineralization of Nitrogen from Organic Wastes to Ryegrass and Wheat Crops. Bioresource Technology, 98, 3265-3268. http://dx.doi.org/10.1016/j.biortech.2006.07.014

[5] Evers, G.W. (2002) Ryegrass-Bermudagrass Production and Nutrient Uptake When Combining Nitrogen Fertilizer with Broiler Litter. Agronomy Journal, 94, 905-910. http://dx.doi.org/10.2134/agronj2002.9050

[6] Vagstad, N., Broch-Due, A. and Lyngstad, I. (2001) Direct and Residual Effects of Pulp and Paper Mill Sludge on Crop Yield and Soil Mineral N. Soil Use and Management, 17, 173-178. http://dx.doi.org/10.1079/SUM200172

[7] Vasconcelos, E., Cabral, F. and Cordovil, C.M.S. (1999) Wheat Yield and Leachability of Phosphorus and Nitrogen in Pig Slurry Amended Soils. Communications in Soil Science and Plant Analysis, 30, 2245-2257. http://dx.doi.org/10.1080/00103629909370369

[8] Lu, J.B. and Li, X. (2006) Review of Rice-Fish-Farming Systems in China-One of the Globally Important Ingenious Agricultural Heritage Systems (GIAHS). Aquaculture, 260, 106-113. http://dx.doi.org/10.1016/j.aquaculture.2006.05.059

[9] Haroon, A.K.Y. and Pittman, K.A. (1997) Rice-Fish Culture: Feeding, Growth and Yield of Two Size Classes of Puntius gonionotus Bleeker and Oreochromis spp. in Bangladesh. Aquaculture, 154, 26l-281.

[10] Youssouf, A., Saidou, A., Mama, D., Fiogbé, E.D. and Micha, J.-C. (2012) Evaluation of Nitrogen and Phosphorus Wastes Produced by Nile Tilapia (Oreochromis niloticus L.) Fed Azolla-Diets in Earthen Ponds. Journals of Environmental Protection, 3, 502-507.

[11] Accodji, J.M.M., Fiogbé, E.D. and Gangbazo, K.H. (2009) Essai de valorisation d’Azolla (Azolla microphylla Kaulf) dans la production porcine en zone humide. International Journal of Biological and Chemical Sciences, 3, 890-898.

[12] Fiogbé, E.D. and Gangbazo, K.H. (2005) Production porcine avec Azolla. Actes des 2èmes Journées Scientifiques Internationales des Universités Nationales du Bénin, 13-16 avril 2004, 142-154.

[13] Agadjihouèdé, H., Montchowi, E., Chikou, A. and Lalèyè, P.A. (2011) Libération comparée de sels dans l'eau par la minéralisation de l'azolla, la bouse de vache, la fiente de volaille et les sons de riz et de maïs utilisés en pisciculture. International Journal of Biological and Chemical Sciences, 5, 1883-1897.

[14] Djissou, A.S. (2012) Production d'aliments vivants (zooplancton) à partir des déjections de porcs pour nourrir les larves de poissons: Détermination des doses optimales. Mémoire de Master en Hydrobiologie Appliquée. Option: Aquaculture, Université d'Abomey-Calavi, Cotonou, 44 p.

[15] Qiu, S., Mc Comb, A.J. and Bell, R.W. (2013) Leaf Litter Decomposition and Nutrient Dynamics in Woodland and Wetland Conditions along a Forest to Wetland Hillslope. International Scholarly Research Network. ISRN Soil Science, 2012, Article ID: 346850.

[16] Hartemink, A.E. and O'Sullivan, J.N. (2001) Leaf Litter Decomposition of Piper aduncum, Gliricidia sepium, and Imperata cylindrica in the Humid Lowland of Papua New Guinea. Plant and Soil, 230, 115-124. 
http://dx.doi.org/10.1023/A:1004868502539

[17] Tian, G., Kang, B.T. and Brussaard, L. (1992) Biological Effects of Plant Residues with Contrasting Chemical Compositions under Humid Tropical Conditions-Decomposition and Nutrient Release. Soil Biology and Biochemistry, 24, 1051-1060. http://dx.doi.org/10.1016/0038-0717(92)90035-V

[18] Kanninkpo, C. (2013) Synthèse de quelques méthodes d’analyses utilisées par le Laboratoire des Sciences du Sol, Eaux et Environnement (LSSEE/CRA Agonkanmey/INRAB) pour les produits végétaux; Rédigé sur la base des documents de travail; 2 p.

[19] Rodier, J. (1996) L’Analyse de l'eau. eaux naturelles, eaux résiduelles, eau de mer. $8{ }^{\text {ème }}$ Edition, DUNOD, Paris, 1383 p.

[20] Dourmand, J.Y. and Henry, Y. (1994) Influence de l'alimentation et des performances sur les rejets azotés du porc. Institut National de la Recherche Agronomique (INRA), Production animale (ProdAnim), 7, 263-274.

[21] Corpen (1996) Estimation des rejets d'azote et de phosphore des élevages de porcs. 23 p.

[22] Faure, P. (2011) Digestion et Absorption des glucides. UE de biochimie métabolique. Université Joseph Fourrier Grenolde 1, Etude de Santé, 1 ième année, 31 p.

[23] Crevieu, G. (1999) Digestion des protéines végétales chez les monogastriques. Exemple des protéines de pois. Institut National de la Recherche Agronomique (INRA), Production animale (ProdAnim), 12, 147-161.

[24] Bernard, C., Côté, C., Côté, D., Girou, M., Grégoire, R., Joncas, R. and Martin, D.Y. (2003) Commission sur le développement durable de la production porcine au Québec. Mémoire de l'Institut de recherche et de développement en agroenvironnement (Irda) Inc., Sainte-Marie, 41 p.

[25] Belghiti, M.L., Chahlaoui, A., Bengoumi, D. and EL Moustaine, R. (2013) Etude de la qualité physico -chimique et bactériologique des eaux souterraines de lanappe plio-quaternaire dans la région de meknès (maroc). Larhyss Journal, 14, 21-36.

[26] Brault, J.L. (1989) Mémento Technique de l'eau. Ed. Technique et Documentation, Paris, 3-119.

[27] Chikou, A. (2011) Pisciculture: Notes de cours à l'intention des étudiants du Master 1 en Hydrobiologie et Aquaculture. Université d'Abomey-Calavi, Cotonou, 86 p.

[28] Cornaz (2004) Evaluation du statut trophique d'un canal de drainage sous l'impact des pollutions d'origines diffuses et ponctuelles: Le cas du Grand Canal de la plaine du Rhône. 180 p.

[29] Gominan, O.S.A. (1999) Contribution de l'étude écologique et de la biologie des espèces de poisson du genre Clarias dans la valée de l’Ouémé: Habitat, Alimentation, Croissance et Reproduction. Thèse de Doctorat d’Ingénieur Agronome, FSA/UAC, $110 \mathrm{p}$.

[30] Abouzid, H. and Outair, A. (1991) Les Nitrates dans les eaux. $7^{\text {ème } C o n g r e s ~ M o n d i a l e ~ d e s ~ r e s s o u r c e s ~ e n ~ e a u, ~ V o l . ~ 2, ~}$ Rabat, 13-18 Mai 1991.

[31] Wedmeyer (1997) In Melard Ch Bases biologiques de l'aquaculture. Note de cours. DES Aquaculture, CEFRA, Université de Liège, Liège, 213 p.

[32] Chapman, D. and Kimstach, V. (1996) Selection of Water Quality Variable. W of Biota, Sediments and Water Quality Assessments: A Guide to of the Use of Biota. In: Sediments and Water in Environment Monitoring, 2nd Edition, Chapmam Edition, E\& FN Spon, London, 59-126.

[33] Huber, G. and Schaub, C. (2011) Guide des fertilisations Azotés utilisables en Bio, Paris, 14 p.

[34] IBGE (2005) Qualité physico-chimique et chimique des eaux de surface: Cadre général. 4.

[35] Derwich, E., Beziane, Z., Benaabidate, L. and Belghyti, D. (2008) Evaluation de la qualité des eaux de surface des Oueds Fes et Sebou utilisées en agriculture maraichère au Maroc. Larhyss Journal, 7, 59-77.

[36] El Hafiane, F., Rami, A. and El Hamouri, B. (2003) Mécanismes d'élimination de l'azote et du phosphore dans un chenal algal à haut Rendement. Revue des sciences de l'eau/Journal of Water Science, 16, 157-172.

[37] Dovonou, F., Aina, M., Boukari, M. and Alassane, A. (2011) Pollution physico-chimique et bactériologique d'un écosystème aquatique et ses risques écotoxicologiques: Cas du lac Nokoue au Sud Benin. International Journal of Biological and Chemical Sciences, 5, 1590-1602.

[38] Voermans, J.A.M., Verdoes, N. and Hartog, L.A. (1994) Environmental Impact of Pig Farming. Pig News and Information, 15, 51-54.

[39] Moal, J.F., Martinez, J., Guiziou, F. and Coste, C.M. (1995) Ammonia Volatilization Following Surface-Applied Pig and Cattle Slurry in France. Journal of Agricultural Science, 125, 245-252. http://dx.doi.org/10.1017/S0021859600084380

[40] Kermarrec, C. and Robin, P. (2002) Emissions de gaz azotés en élevage de porcs sur litière de sciure. Journées de la Recherche Porcine, 34, 155-160.

[41] Hassan, R., Khadija, E., Belghyti, D. and Hadji, M. (2013) Physico-Chemical Waste Water Unit of Sugar SUNABEL 
H. K. J. Bokossa et al.

Mechraa Belksiri. ScienceLib Editions Mersenne, 5.

[42] Rodier (2012) Analyse de l'eau. 20225 p.

[43] Laferriere, M.(1996) L'industrie porcine et les risques reliés à la santé humaine. Vecteur Environnement, 29, 27-31.

[44] Salanitro, J.P., Blake, I.G. and Muirhead, P.A. (1977) Isolation and Identification of Fecal Bacteria from Adult Swine. Applied and Environmental Microbiology, 33, 79-84. 
Scientific Research Publishing (SCIRP) is one of the largest Open Access journal publishers. It is currently publishing more than 200 open access, online, peer-reviewed journals covering a wide range of academic disciplines. SCIRP serves the worldwide academic communities and contributes to the progress and application of science with its publication.

Other selected journals from SCIRP are listed as below. Submit your manuscript to us via either submit@scirp.org or Online Submission Portal.
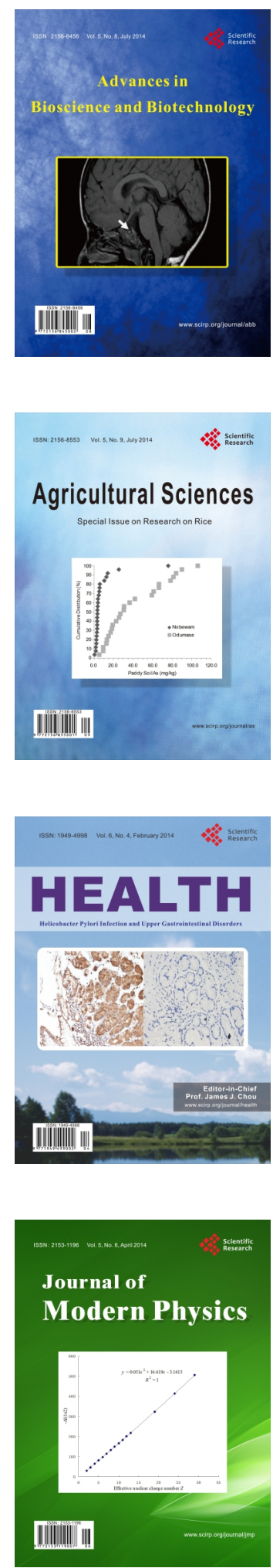
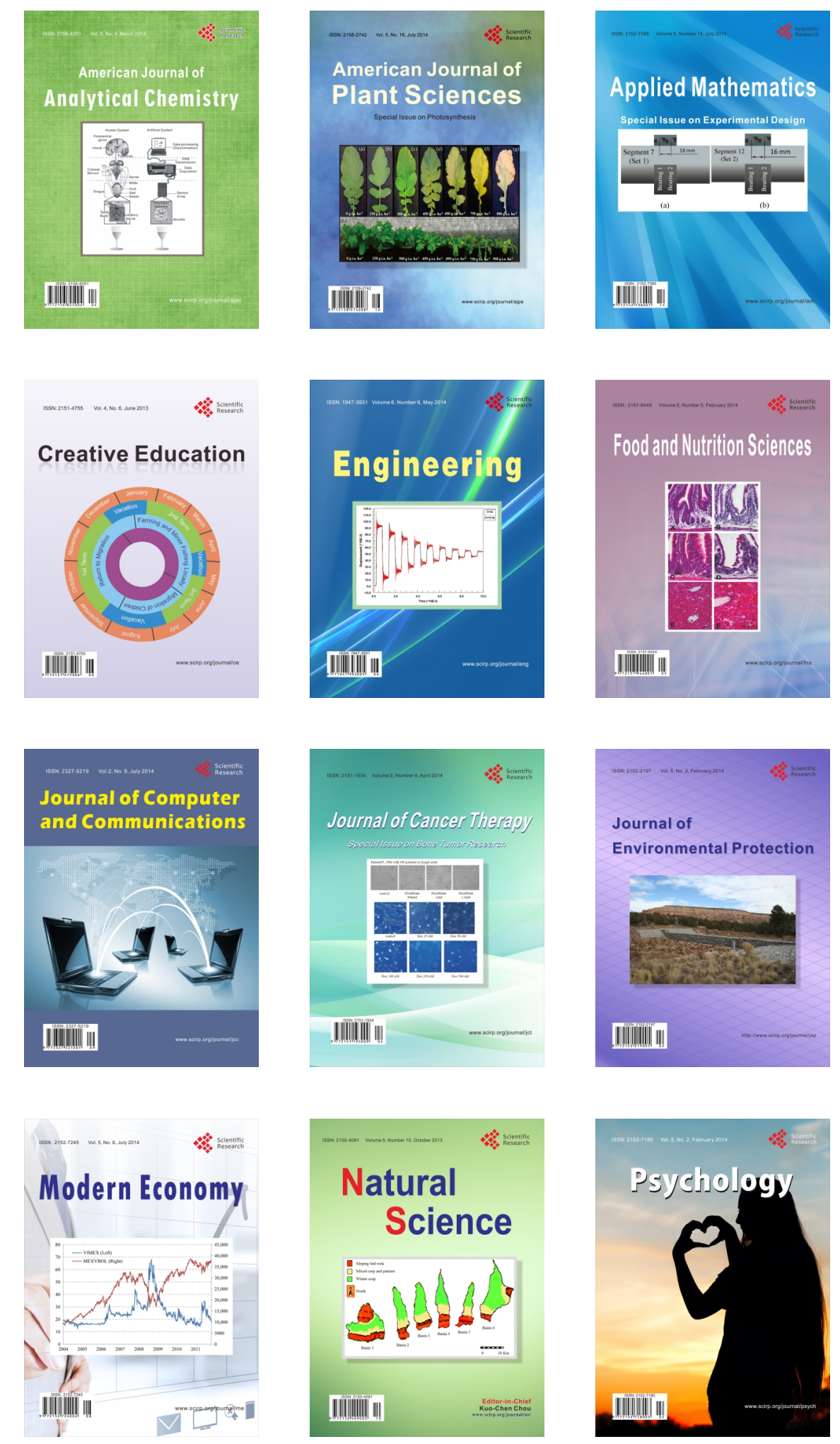